University of Nebraska - Lincoln

DigitalCommons@University of Nebraska - Lincoln

$12-2008$

\title{
Isotopic Evidence of Methane Oxidation across the Surface Water-Ground Water Interface
}

\author{
Diego Andrés Riveros-Iregui \\ University of Nebraska - Lincoln, driveros2@unl.edu \\ Jennifer Y. King \\ University of Minnesota - Twin Cities
}

Follow this and additional works at: https://digitalcommons.unl.edu/natrespapers

Part of the Natural Resources and Conservation Commons

Riveros-Iregui, Diego Andrés and King, Jennifer Y., "Isotopic Evidence of Methane Oxidation across the Surface Water-Ground Water Interface" (2008). Papers in Natural Resources. 213.

https://digitalcommons.unl.edu/natrespapers/213

This Article is brought to you for free and open access by the Natural Resources, School of at DigitalCommons@University of Nebraska - Lincoln. It has been accepted for inclusion in Papers in Natural Resources by an authorized administrator of DigitalCommons@University of Nebraska - Lincoln. 


\title{
Isotopic Evidence of Methane Oxidation across the Surface Water-Ground Water Interface
}

\author{
Diego A. Riveros-Iregui \\ Department of Geology and Geophysics, University of Minnesota, \\ 310 Pillsbury Dr. SE, Minneapolis, Minnesota, USA 55455 \\ Jennifer Y. King \\ Department of Soil, Water and Climate and Department of Ecology, Evolution, and Behavior, \\ University of Minnesota, 439 Borlaug Hall, 1991 Upper Buford Circle, St. Paul, Minnesota, USA 55108
}

\begin{abstract}
Biogenic methane $\left(\mathrm{CH}_{4}\right)$ from wetlands plays a crucial role in the carbon cycle, but the dynamics of dissolved methane flux across the surface water-ground water interface remain poorly understood. This study focused on the effects of spatial transformation of dissolved methane and the role of ground-water recharge in the distribution of dissolved methane across the surface water-ground water interface. Here we present carbon isotopic measurements of biogenic methane and dissolved inorganic carbon (DIC) from the Sarita Wetland, on the St. Paul Campus of the University of Minnesota, and also in six monitoring wells located down gradient from the wetland. The $\delta^{13} \mathrm{C}$ values of $\mathrm{CH}_{4}$ vary between -10.6 and $-58.4 \%$, and the $\delta^{13} \mathrm{C}$ values of DIC vary between +0.8 and $-14.1 \%$ across the study site. Based on dissolved methane concentrations during the growing season, we estimate that ground water methane represents $8 \%-38 \%$ of total methane dissolved in the wetland. Using the carbon isotopic composition of methane and knowledge of the site hydrology, we found that the degree of methane oxidation increased as methane moved away from the wetland along the ground water flowpath. The proportion of methane oxidized ranged between $4 \%$ and $99 \%$ with most of the methane oxidation occurring within the first $120 \mathrm{~m}$ from the wetland. The degree of oxidation within the wetland itself varied from $81 \%$ in the spring to $99 \%$ during the winter, suggesting that oxidation of dissolved methane occurs more rapidly in surface waters than in ground water recharge. This study shows that ground water flow paths are a primary control on the export of dissolved methane produced in wetlands. This study also demonstrates that $\mathrm{C}$ stable isotopes can be used to study transport of dissolved methane across the surface water-ground water interface, accounting for methane oxidation during transport.
\end{abstract}

Keywords: carbon stable isotopes, dissolved methane transport, ground water, wetland

\section{Introduction}

Temperate and boreal wetlands represent an enormous carbon reservoir and are considered an important source of atmospheric methane $\left(\mathrm{CH}_{4}\right.$; Reeburgh 2003). Major research efforts have focused on measuring methane emissions across the air-water interface (Whiting and Chanton 1993, Xing et al. 2005), understanding the role of methane in the global carbon (C) cycle (Tyler 1991, Wahlen 1993, 2005), and determining its potential as a greenhouse gas (Whiting and Chanton 2001, Bousquet et al. 2006). Furthermore, scales of methane oxidation studies have usually been at the profile level. Researchers have focused primarily on methane fluxes in wetland or lake profiles (Strayer and Tiedje 1978, Frenzel and Karofeld 2000), soil profiles (Giani et al. 2002, Teh et al. 2005), or landfill cover profiles (Liptay et al. 1998, De Visscher and Van Cleemput 2003, De Visscher et al. 2004). However, measurements of dissolved methane oxidation across the surface water-ground water in- 
terface are limited, and the temporal and spatial variability of methane oxidation involving subsurface flow remains poorly understood.

Stable isotopes have been widely used to study methane oxidation (Bastviken et al. 2002, Van Breukelen and Griffioen 2004). Microbially mediated oxidation of methane discriminates against ${ }^{13} \mathrm{C}$, leaving residual methane enriched in ${ }^{13} \mathrm{C}$ (Barker and Fritz 1981, Alperin et al. 1988). Using stable carbon isotopes as a tracer for methane oxidation in a landfill-leachate plume, recent studies show that $84 \%$ of methane is oxidized within $200 \mathrm{~m}$ from the landfill (Grossman et al. 2002). Similar studies have found variable oxidation rates $(24 \%-46 \%)$ during transport through landfill covers (Bergamaschi et al. 1998, Liptay et al. 1998).

In wetland soils, ground water levels exert the most important control on methane emissions to the atmosphere (Liblik et al. 1997) because they affect the vertical extension of the oxidation zone in the soil. Given this control, the coupling of ground water and dissolved methane dynamics is critical to understanding the transformation of methane beyond the profile scale. In fact, carbon loss via ground water can be greater than carbon loss to the atmosphere in peatland settings (Waddington and Roulet 1997). Ground water recharge may serve as a dilution mechanism in settings where dissolved methane is found in the subsurface (Simpkins and Parkin 1993). In a recent study, Darling and Gooddy (2006) demonstrated that detectable concentrations of ground water methane can be found under a range of redox conditions, highlighting the potential for transport and relocation. Thus the importance of ground water transport of dissolved methane is widely accepted (e.g., Barker and Fritz 1981, Gooddy and Darling 2005), but currently there is a lack of studies that address it within the context of connected wetland-ground water settings.

This study targeted the spatial pattern of dissolved methane oxidation occurring within a small freshwater wetland and in the ground water flowpath down gradient from it. The specific goal of this work was to evaluate the dynamics of dissolved methane flux across the surface water-ground water interface and address the following questions: 1) how much methane from the wetland is lost via ground water? and 2) what is the degree of methane oxidation across the surface water-ground water interface and along the ground water flowpath? To address these questions, the natural abundances of stable carbon isotopes of methane and dissolved inorganic carbon (DIC) were measured to quantify methane oxidation occurring in the wetland and in the ground water flowpath. The working hypothesis for this study is that methane produced in the wetland has a distinctive isotopic signature, so that methane oxidation is measurable within the wetland's catchment as methane is translocated from the wetland through ground water recharge pathways.

\section{Methods}

\section{Site Description}

The Sarita Wetland is a 3-ha natural wetland located on the south side of the University of Minnesota, St. Paul campus $\left(44.98^{\circ} \mathrm{N}, 93.18^{\circ} \mathrm{W}\right.$, and $270 \mathrm{~m}$ above sea level). The wetland collects runoff water from the campus and drains it into a storm water duct located at its southeast end. Ground water seepage occurs at the northeast end of the wetland, as indicated by a differential in hydraulic head monitored at two ground water wells located in this end, and by rapid thawing of the ice cover during the winter. According to the Canadian Wetland Classification System (NWWG 1997), this wetland is classified as a fen due to its fluctuating water table, relatively high $\mathrm{pH}(\sim 7.1)$, high dissolved mineral content, and abundant brown mosses. High organic matter accumulation exists due to high primary productivity, waterfowl nutrient input, and slow decomposition. Vegetation within this wetland is dominated by cattail (T. glauca), evenly distributed throughout the wetland. The unconsolidated sediments (loose sediments) were measured to be $2.5 \mathrm{~m}$ thick in June 2004.

Ground water within the Minneapolis-St. Paul basin is stored in both the Quaternary deposits and bedrock. The Quaternary deposits consist of sand and gravel outwash at the surface within the glacial debris. A high degree of spatial variability in transmissivity and hydraulic conductivity values exist due to the heterogeneity typical of glacial deposits such as these. Ground water samples taken for this study come from the Quaternary deposits.

\section{Sampling}

Samples for dissolved methane and DIC analysis were collected on the following dates in 2004: February 23, March 17, April 11, April 23, May 19, and June 14. Given that no major differences existed in wetland characteristics and vegetation cover throughout the wetland, six sites were selected forming a $3 \times 2$ grid to ensure coverage from all parts of the wetland. A portable sampling pump (Masterflex L/S No. 7570-10, Cole-Parmer Instrument Company, Vernon Hills, IL) was used to extract water at the sediment-water interface, maintaining low 
pumping rates $(<0.5 \mathrm{LPM})$ to minimize disturbance. Water was pumped for a few minutes before taking the sample, so the possibility of degassing of the samples would be minimized. Samples were collected in triplicate in 27$\mathrm{ml}$ amber glass vials leaving no air space and sealed with aluminum seals and rubber septa with a Teflon cover inside. Glass vials were immediately refrigerated and carried to the lab to be analyzed within 2 days of collection.

Ground water samples were taken from six monitoring wells (MW-1, MW-1D, MW-2, MW-3, MW-9, and MW-10) already in place and semi-distributed in the catchment (Figure 1), and following similar procedures to the wetland samples. MW-1D was screened below the water table and it can be considered a piezometer. MW-1D was useful to calculate difference in hydraulic potential between the wetland and deep ground water (for more on the use of wells and piezometers see Methods description in Bradley et al. 2007). To collect ground water, a submersible pump was lowered into each well and at least 1-2 times the borehole volume was extracted before collecting the sample. Depth of completion of these wells ranged between 3.3 and $25 \mathrm{~m}$ below the surface (Figure 1).

\section{Analytical Measurements}

Methods for extraction of DIC were modified from Miyajima et al. (1995). A headspace was created inside each of the 27-ml glass vials by concurrently removing 5 $\mathrm{ml}$ of water through the septum with a gas-tight syringe (Hamilton Co., Reno, NV) and replacing it with ultra pure, research-grade nitrogen $\left(\mathrm{N}_{2}\right)$ gas. Samples were subsequently acidified by injection of $0.5 \mathrm{ml}$ of $\mathrm{CO}_{2}$ free hydrochloric acid $(6 \mathrm{~N})$ and equilibrated by hand shaking so the $\mathrm{CO}_{2}$ dissolved in the water would degas into the headspace. The sample bottles were left upside down in the dark for at least two hours before analysis. Gas concentrations were quantified by gas chromatography on a Perkin-Elmer Auto-system gas chromatograph (GC) equipped with a fused silica capillary column (30 m, $0.53 \mathrm{~mm}$ internal diameter, Carboxen 1010 PLOT, Supelco), a flame ionization detector (FID), and a thermal conductivity detector (TCD). Research-purity argon was used as the carrier gas at a flow rate of $20 \mathrm{ml} / \mathrm{min}$. The column temperature step-heating was performed as follows: $40^{\circ} \mathrm{C}$ for $1.7 \mathrm{~min}$, with a $40^{\circ} \mathrm{C} /$ min increase up to $220^{\circ} \mathrm{C}$, and continuing at $220^{\circ} \mathrm{C}$ for 20 $\mathrm{min}$. This system was calibrated by using a commercial mixture of $1 \% \mathrm{CO}_{2}$ and $1 \% \mathrm{CH}_{4}$ balanced in $\mathrm{N}_{2}$ (Matheson Tri Gas, Newark, CA). Concentrations were calculated by using Henry's law and are expressed in mmol $1^{-1}$. Uncertainties in reported concentrations are estimated to be within $\pm 5 \%$.

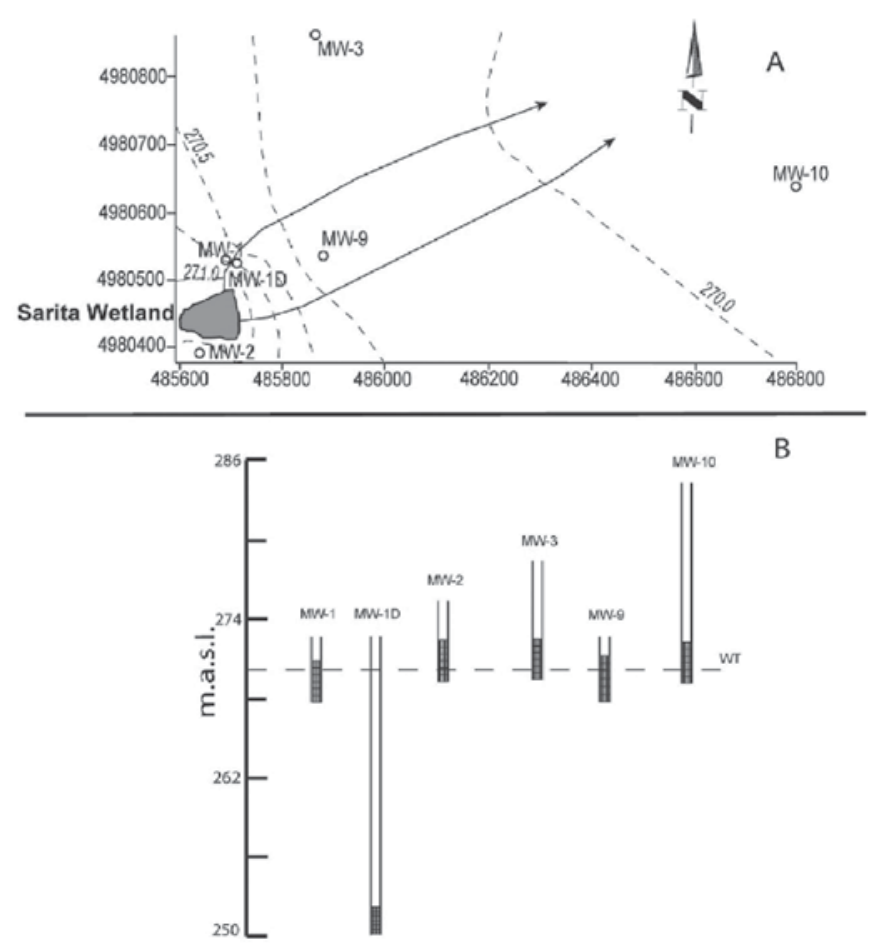

Figure 1. A) Ground water contours of the Sarita Wetland watershed. Contour interval is $0.25 \mathrm{~m}$. Solid arrows indicate flowpath. Axes are in the Universal Transverse Mercator (UTM) grid system. B) Relative elevations and depths of monitoring wells and their screening (mesh). The dashed line represents the water table and the elevation values are given in meters above sea level. Actual variations in water table elevation cannot be represented at the scale of this figure, and therefore a flat water table is shown.

The procedure to extract dissolved methane was modified from McAuliffe (1971) and is summarized here. After collection in the field and transport to the lab, $2.5 \mathrm{ml}$ of water were extracted from each of the 27$\mathrm{ml}$ glass vials in the same manner as for DIC. Next, 2.5 $\mathrm{ml}$ of $\mathrm{N}_{2}$ were added into the syringe and then vigorously hand-shaken for 3-5 min to obtain equilibrium between the two phases. Concentrations were quantified in a similar manner and same equipment as for DIC and are expressed in $\mathrm{mmol}^{-1}$.

Isotopic analyses were performed using a cryofocusing trace gas preconcentrator (Micromass TraceGas, Manchester, England) and continuous flow isotope ratio mass spectrometer (Fisons Optima, Manchester, England). The TraceGas preconcentrator methods for methane analysis are based on methods similar to those described by Rice et al. (2001) and Miller et al. (2002) and used by many others (e.g., Tarasova et al. 2006, Kinnaman et al. 2007). The operation of the Trace- 
Gas preconcentrator is summarized here and described in more detail by Fisher et al. (2006). Once gas samples were extracted from water samples as previously described, gas samples were transferred using a gas-tight syringe (Hamilton Co., Reno, NV) from glass vials into glass flasks fitted with a septum port. On the TraceGas system, air samples to be analyzed for $\delta^{13} \mathrm{C}_{-}-\mathrm{CH}_{4}$ were passed through chemical traps (magnesium perchlorate and Carbosorb) to remove water and $\mathrm{CO}_{2}$. Samples were then passed through a combustion furnace $\left(1,000^{\circ} \mathrm{C}\right)$ containing platinum, nichrom, and copper $(\mathrm{Pt} / \mathrm{NiCr} / \mathrm{Cu})$ oxidation catalysts for quantitative conversion of $\mathrm{CH}_{4}$ to $\mathrm{CO}_{2}$. The oxidation catalysts were regularly reconditioned overnight with ultra-high purity $\mathrm{O}_{2}$. The resulting $\mathrm{CO}_{2}$ was retained in a cryofocusing trap and then passed through a Nafion membrane to remove water before gas chromatographic separation on a PoraPLOT Q GC column and passage to the mass spectrometer through an open split. Air samples to be analyzed for $\delta^{13} \mathrm{C}-\mathrm{CO}_{2}$ were not passed through chemical traps to remove $\mathrm{CO}_{2}$ or through the combustion furnace.

Isotopic compositions are reported relative to Vienna Pee Dee Belemnite (VPDB) standards, and ratios are expressed in delta notation:

$$
\delta^{13} \mathrm{C}(\%)=\left[\left(R_{\text {sample }} / R_{\text {std }}\right)-1\right] \times 1000
$$

where $R_{\text {sample }}$ and $R_{\text {std }}$ refer to the ${ }^{13} \mathrm{C} /{ }^{12} \mathrm{C}$ ratio in the sample and in the standard, respectively. As laboratory reference standards we used atmospheric $\mathrm{CO}_{2}$ standards obtained from the National Oceanic and Atmospheric Administration Earth System Research Laboratory, and analyzed by the Stable Isotope Laboratory at the University of Colorado and traceable to National Bureau of Standards. Although an international standard material for the isotopic composition of methane does not exist, an in-house methane standard was maintained and analyzed along with the samples. Based on multiple analyses of these standards the analytical uncertainty is within $\pm 0.2 \%$ o for both $\delta^{13} \mathrm{C}_{-}-\mathrm{CO}_{2}$ and $\mathrm{\delta}^{13} \mathrm{C}-\mathrm{CH}_{4}$.

\section{Methane Oxidation}

Fractionation factors were used to determine the origin of biogenic methane and examine degree of oxidation (Whiticar 2000). Assuming that the system was in steady state, the fractionation factor $\alpha_{\mathrm{CO}_{2}-\mathrm{CH}_{4}}$ was defined as:

$$
\alpha_{\mathrm{CO}_{2}-\mathrm{CH}_{4}}=\left[\left(\delta^{13} \mathrm{CO}_{2}+1000\right) /\left(\delta^{13} \mathrm{CH}_{4}+1000\right)\right]
$$

where $\delta^{13} \mathrm{CO}_{2}$ is the signature of DIC as $\mathrm{CO}_{2}$ and $\delta^{13} \mathrm{CH}_{4}$ is the signature of dissolved methane. To measure methane oxidation, we used the Rayleigh model, in which the isotopic composition of methane found in ground water is related to the isotopic composition of methane in the anoxic zone by the following equation (Bergamaschi et al. 1998):

$$
\begin{aligned}
\delta^{13} \mathrm{CH}_{4 \mathrm{i}}-\delta^{13} \mathrm{CH}_{4 \text { source }}= & {\left[\left(\delta^{13} \mathrm{CH}_{4 \text { source }}+1000\right)\right.} \\
& \times((1 / \alpha)-1) \times \ln (\mathrm{F})]
\end{aligned}
$$

where $\mathrm{\delta CH}_{4 i}$ is the isotopic value of methane at any time $i, \mathrm{SCH}_{4 \text { source }}$ is the isotopic composition of methane at the source, $a$ is the fractionation factor, and $F$ is the fraction of residual methane, which for this study is referred to as the remaining concentration of dissolved methane. Statistical analyses were performed in Sigmaplot 10.0, and error bars reported represent one standard deviation of the means.

\section{Results and Discussion}

In the wetland, DIC concentrations ranged from 0.43 to $2.63 \mathrm{mmol} \mathrm{l}^{-1}$, and $\delta^{13} \mathrm{C}$-DIC values varied from -5.1 to $-11.0 \%$ o during the length of the study (Table 1). Methane concentrations varied from 0.0227 to $0.3118 \mathrm{mmol} \mathrm{l}^{-1}$, and $\delta^{13} \mathrm{C}_{-} \mathrm{CH}_{4}$ values ranged from -12.1 to $-50.2 \%$. In general, more positive values of $\delta^{13} \mathrm{CH}_{4}$ were found when the wetland was ice covered and the sediments were frozen. More negative values of $\delta^{13} \mathrm{C}_{-} \mathrm{CH}_{4}$ were found after thawing and throughout the growing season.

In ground water, DIC concentrations ranged from 1.09 to $9.23 \mathrm{mmol}^{-1}$, and $\delta^{13} \mathrm{C}$-DIC values ranged from +0.8 to $-14.1 \%$ o during the length of the study. Methane concentrations varied from levels below detection limit to $1.728 \mathrm{mmol} 1^{-1}$ and $\delta^{13} \mathrm{C}_{-} \mathrm{CH}_{4}$ values ranged from -10.6 to $-58.4 \%$. The more positive values of $\delta^{13} \mathrm{CH}_{4}$ were measured in MW-1D and MW10 , and the more negative values were measured in MW-1 and MW-2. Prior to snowmelt, methane concentrations were low in ground water near the wetland $\left(\sim 0.01 \mathrm{mmol} \mathrm{l}^{-1}\right)$, perhaps because methane production during the winter is low and ground water recharge is so slow that methane does not reach the ground water. After snowmelt, methane concentrations increased in both the wetland and ground water, and the $\delta^{13} \mathrm{C}_{-} \mathrm{CH}_{4}$ values became significantly more negative. This increase of dissolved methane concentrations in the ground water during the growing season is a combined effect of increased methane production at the surface and greater ground water recharge driven by snowmelt and rain. 
Table 1. Concentration and isotopic composition of dissolved inorganic carbon (DIC) and methane $\left(\mathrm{CH}_{4}\right)$. Delta values are expressed with respect to VPDB standards. Dash indicates either not determined or not detected.

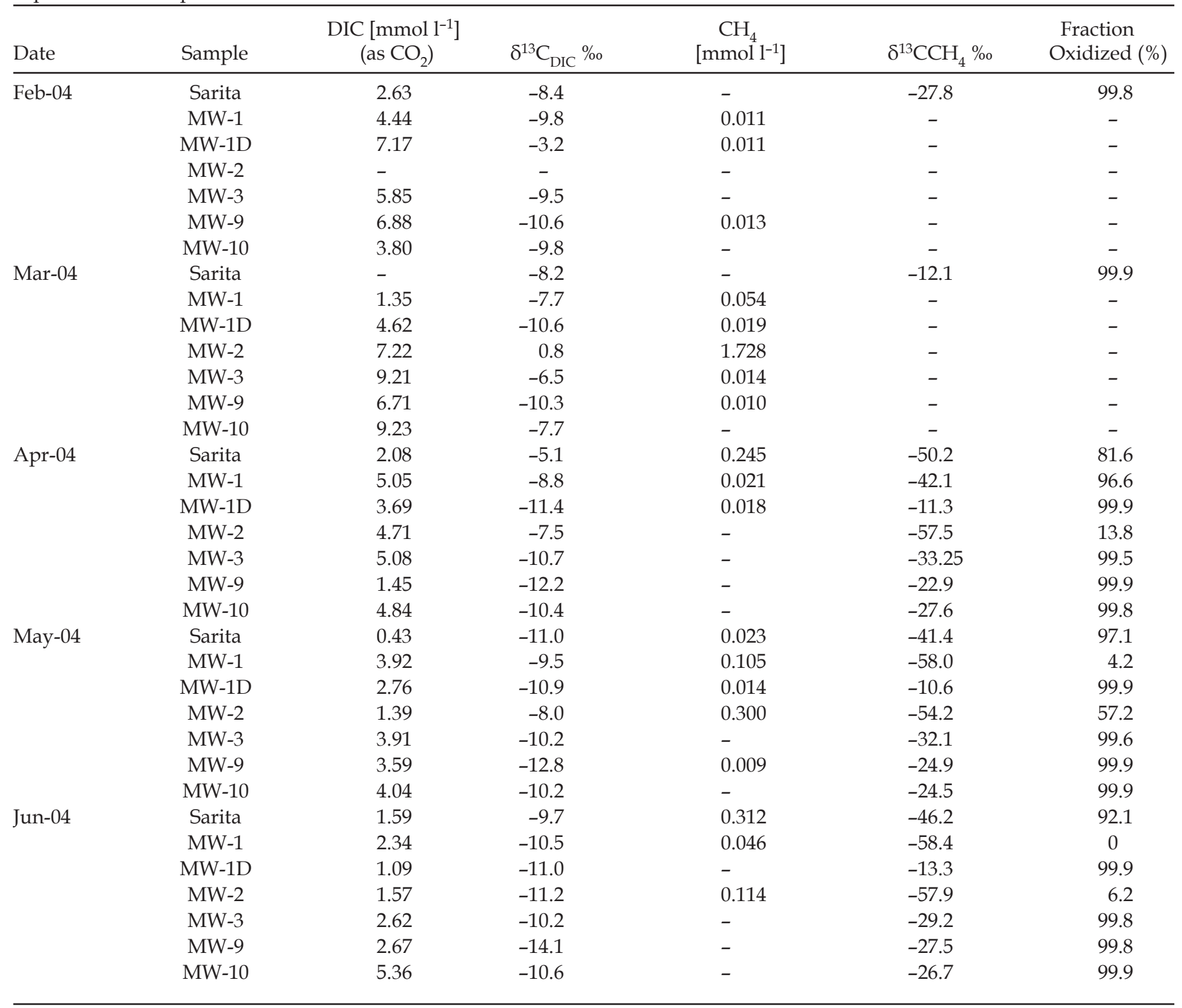

In general, $\delta^{13} \mathrm{C}-\mathrm{CH}_{4}$ values of dissolved methane in ground water were more positive with increasing distance from the wetland (Figure 2). When $\delta^{13} \mathrm{C}_{-} \mathrm{CH}_{4}$ values were plotted against the natural log of distance, samples collected from MW-1, MW-2, MW-3, MW-9, and MW-10 exhibited a linear relationship $\left(\mathrm{r}^{2}=0.63\right)$, indicating a logarithmic relation among samples from these sites. This relationship was the result of a logarithmic decay due to the discrimination against ${ }^{13} \mathrm{CH}_{4}$ during methane oxidation (Abichou et al. 2006) occurring from the same methane pool, where the degree of isotopic fractionation has been shown to decrease with decreasing methane concentrations (Teh et al. 2006). However, samples collected from MW-1D and MW-9 did not follow the same relationship. Due to the heterogeneity of the sediments in this basin, samples collected from MW-9 likely followed a longer ground water flowpath, rather than a simple "straight line" from the wetland (as measured in Figure 2), so a higher degree of oxidation occurred resulting in more positive $\delta^{13} \mathrm{C}_{-} \mathrm{CH}_{4}$ values. While MW-1D was very close to the wetland, it did not show similar $\delta^{13} \mathrm{C}^{-\mathrm{CH}_{4}}$ values to $\mathrm{MW}-1$ or $\mathrm{MW}-2$. Instead, MW-1D, which was the deepest well in this study (Figure 1), consistently showed the most positive $\delta^{13} \mathrm{C}_{-} \mathrm{CH}_{4}$ values among all sites, reflecting highly oxidized methane. Given that dissolved methane collected in MW1D corresponded to the deepest ground water samples in this study, our results suggest that methane found 


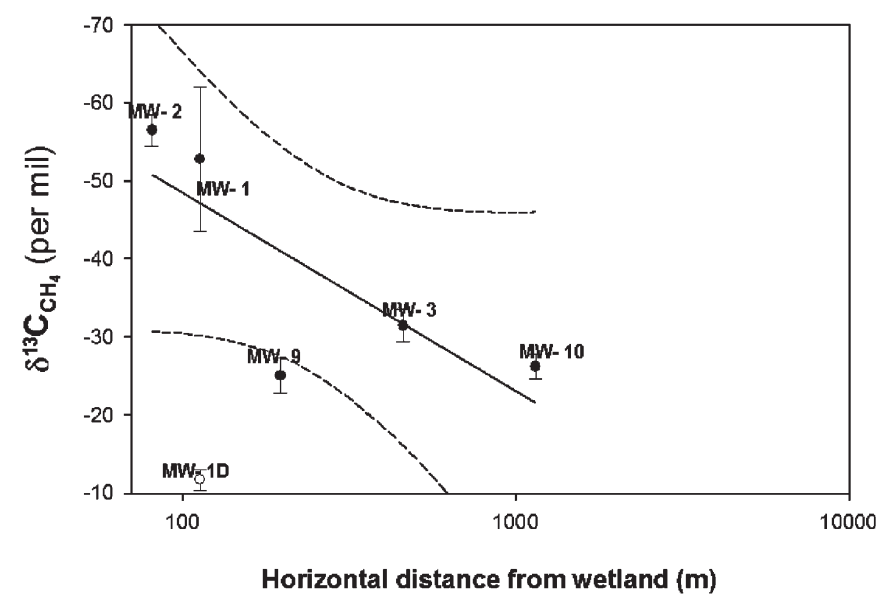

Figure 2. Variation of $\delta^{13} \mathrm{C}-\mathrm{CH}_{4}$ values and horizontal distance from wetland. Horizontal distance is shown on a logarithmic scale. Error bars represent one standard deviation of the mean $(n=3)$ and dashed lines represent 95\% confidence intervals. Note that given the depth of samples from MW-1D (Figure 1), this site was not included in the regression $\left(\mathrm{y}=11.064(\operatorname{Ln}(\mathrm{x}))^{-}\right.$ 99.47; $\mathrm{r}^{2}=0.63$.

in this well was likely the result of a transport mechanism driven by a concentration gradient (diffusion) as opposed to a hydraulic gradient (advection), as occurring in the other wells. Thus diffusion caused methane to migrate from the wetland down into the saturated area, and as a result, the movement of methane away from the wetland was much slower than when caused by advection, allowing more oxidation to occur. Recent studies of pore water methane under peatlands have demonstrated that dissolved methane can diffuse vertically for several meters (Beer and Blodau 2007). However, our attempts to estimate discharge and flow velocities of ground water based on hydraulic conductivity and slug tests were hampered by the high spatial heterogeneity of the sediments, typical of glacial deposits, which led to inaccurate estimates.

The isotopic analyses of biogenic methane in surface and ground water showed consistency at each sampling occasion relative to one another. The $\delta^{13} \mathrm{C}^{-} \mathrm{CH}_{4}$ values of wetland samples were more positive than MW-1 and MW-2 and more negative than MW-3, MW-9, and MW-10 (Figure 3). This pattern indicates that MW-1 and MW-2 contained methane closer in composition to that of the anoxic zone or anoxic "microsites" (as discussed in Darling and Gooddy 2006) and that methane oxidation occurred faster in surface waters than in proximal ground water.

Stable isotopes are commonly used to study methane oxidation (Happell et al. 1994, Zhang et al. 1998, Whiticar 1999), due to discrimination against ${ }^{13} \mathrm{C}$ dur- ing methane oxidation. Various degrees of methane oxidation have been reported by using stable isotopes (Schoell 1980, Whiticar and Faber 1986, Happell et al. 1994, Liptay et al. 1998, Whiticar 2000). To test our original hypothesis that the fate of methane produced in the wetland can be detected in ground water, we used combined analyses of carbon isotopic composition of $\mathrm{CH}_{4}$ and DIC. In February, $\delta^{13} \mathrm{C}_{-} \mathrm{CH}_{4}$ and $\delta^{13} \mathrm{C}$-DIC values in the wetland were -27.8 and $-8.4 \%$, respectively (Figure $3 a$ ). These unusually heavy values are not uncommon for dissolved methane sampled in the water column (Whiticar 1999) and may be the result of methane that remained dissolved in the water column or in the wetland sediments during the cold months. After snowmelt, $\mathrm{\delta}^{13} \mathrm{C}-\mathrm{CH}_{4}$ values became more negative, and this can be interpreted as greater production of methane and shorter time since production. Similar comparisons were made for the months of April, May, and June (Figures $3 b, 3 c$, and $3 d$ ).

To aid in interpreting methane oxidation, the Rayleigh model proposed in Equation 3 can be conceptually read as:

$$
\Delta \mathrm{CH}_{4}=\mathrm{f}\left(\delta^{13} \mathrm{CH}_{4 \text { source' }}, 1 / \alpha, \ln \mathrm{F}\right)
$$

where $\Delta \mathrm{CH}_{4}$ is the change in the $\delta^{13} \mathrm{CH}_{4 \text { source }}$ and is a function of the value of $\delta^{13} \mathrm{CH}_{4 \text { source }}$ itself, the reciprocal of a (the fractionation factor), and the logarithmic change of $\mathrm{F}$ (the fraction of residual methane). Hence, to obtain $\delta \mathrm{CH}_{4}$ source, $\delta^{13} \mathrm{C}-\mathrm{CH}_{4}$ values were compared to $\ln (\mathrm{F})$ (Figure 4$)$ and the regression line of this relationship was extrapolated to intersect the $y$ axis $\left(\mathrm{\delta CH}_{4}\right.$ source $=-58.2 \%$ o $)$. Subsequently, using a range of a values, the Rayleigh model in Equation 3 was fitted to this regression and this yielded a value for a of 1.005 (Figure 4). This a value was introduced into Equation 3 to estimate amounts of methane oxidized at each point.

The amounts of methane oxidized ranged between $4 \%$ and $99 \%$ (Table 1) with most of the oxidation occurring within the first $120 \mathrm{~m}$ from the wetland. Oxidation within the wetland itself varied from $81 \%$ in the spring to $99 \%$ during the winter. This variability in oxidation was likely the result of a shift from combined production-oxidation during the spring to oxidation being predominant during winter. In ground water, oxidation amounts were lower for MW-1 and MW-2, especially during the growing season. This seasonal pattern was likely the result of faster methane transport from wetland to ground water after recharge pathways become active. The fact that oxidation amounts were higher in surface than at depth suggests that oxidation of methane occurs more rapidly in surface waters than in ground 


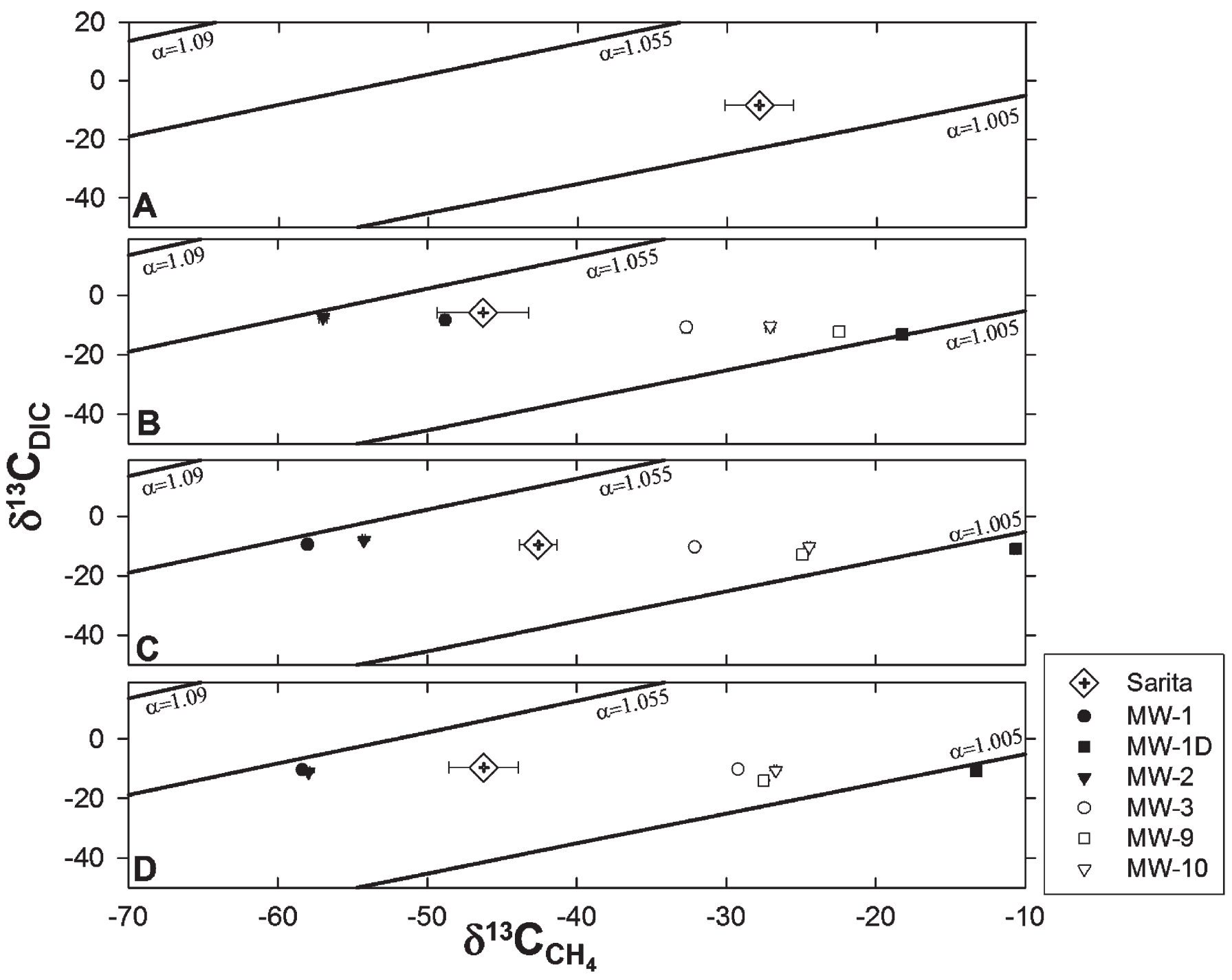

Figure 3. Values of $\delta^{13} \mathrm{C}$-DIC vs. $\delta^{13} \mathrm{C}-\mathrm{CH}_{4}$ for the months of A) February, B) April, C) May, and D) June. No methane was found in the monitoring wells during February. Straight lines represent different fractionation factors as presented in Equation (2). Data points from the wetland are consistently located in the oxidation trajectory between two groups of wells: the group of wells with more negative $\delta^{13} \mathrm{C}-\mathrm{CH}_{4}$ values (MW-1 and MW-2) and the group of wells with more positive $\delta^{13} \mathrm{C}-\mathrm{CH}_{4}$ values (MW-3, MW-9, and $\mathrm{MW}-10$ ), indicating that $\mathrm{CH}_{4}$ oxidation occurs faster in surface waters (wetland) than in proximal ground water (MW-1, MW2). Error bars represent one standard deviation of the mean $(n=3)$.

water recharge. Oxidation amounts calculated for this study were comparable to those reported by Happell et al. $(1994 ; 22 \%-92 \%)$ on methane emitted from Florida swamps and Liptay et al. (1998; $1 \%-68 \%)$ on methane oxidized in landfill cover soils.

According to the ground water table elevation (Figure 1) and data presented in Figures 2, 3, and 4, there is evidence to suggest that methane generated in the wetland was being carried into the ground water. The most negative $\delta^{13} \mathrm{C}_{-}-\mathrm{CH}_{4}$ values were not found in the wetland but in the anoxic zone near it (Figure 5), which was also an active zone for hydrologic exchange due to differences in hydraulic head. Simultaneously, methane concentrations decreased with distance from the wetland (with exception of MW-1D), and the $\delta^{13} \mathrm{C}_{-} \mathrm{CH}_{4}$ values became more positive due to preferential consumption of ${ }^{12} \mathrm{CH}_{4}$ by methane oxidizing bacteria.

The results of this study suggest that connectivity between surface water and ground water is an important contributor to the export of dissolved methane from the wetland. Based on dissolved methane concentrations during the growing season, ground water methane represented $8 \%-38 \%$ of total methane dissolved in the wetland. Methane export was greater during the summer, when wetland and ground water were actively connected. These are important observations as methane 


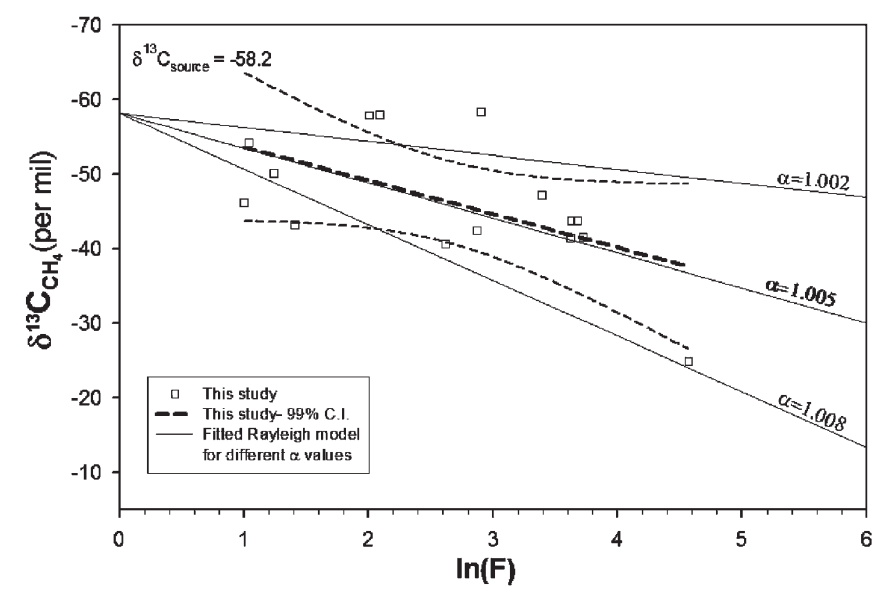

Figure 4. Comparison of $\delta^{13} \mathrm{C}-\mathrm{CH}_{4}$ values and the natural log of the inverse of residual methane $(\ln (\mathrm{F}))$. The $\delta^{13} \mathrm{C}-\mathrm{CH}_{4 \text { source }}$ is estimated to be $-58.2 \%$. A fitted Rayleigh fractionation model allows for estimation of $a=1.005$.

export via ground water recharge is commonly not addressed. Methane emissions from wetlands to the atmosphere in northern latitudes have been estimated to be $40 \mathrm{Tg} / \mathrm{yr}$ (Reeburgh 2003). However, little is known about how much methane is being exported via ground water. The integration of a ground water export component into methane budgets of wetlands (especially those actively connected to ground water) may help constrain such budgets and further our understanding of interactions between the hydrologic and methane cycles. Our results highlight the role of ground water recharge pathways on transport and allocation of components of the methane cycle.

\section{Acknowledgments}

Partial support was provided by the Richard Clarence Dennis Graduate Fellowship from the Department of Geology and Geophysics at the University of Minnesota. J. Yavitt and R. Emanuel gave valuable input on how to improve this manuscript, and J. Chanton and D. Valentine provided insight into estimation of $\mathrm{CH}_{4}$ oxidation. D. Foustoukos and Q. Fu provided assistance with laboratory analyses. Two anonymous reviewers and the associate editor for Wetlands provided helpful comments on an earlier version of this manuscript.

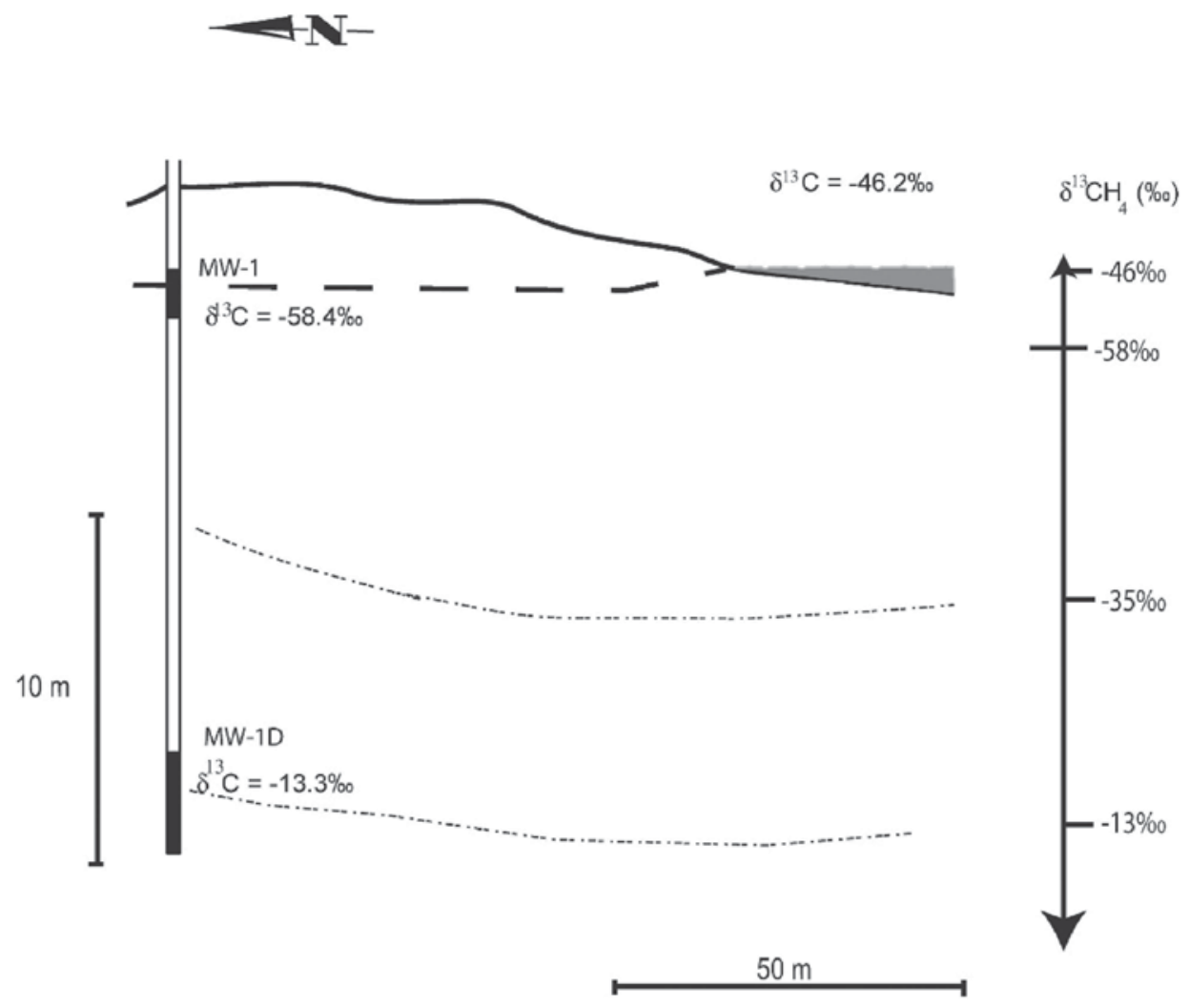

Figure 5. Profile of the carbon isotopic variation from the Sarita Wetland towards MW-1 (upper screen) and MW-1D (lower screen) during June 2004. Since MW-1 and MW-1D are adjacent to each other, they are shown as the same well in this figure. The dashed line represents the water table. The dotted lines are inferred lines of equal isotopic composition. The scale (right) shows a minimum of $-58 \%$ in the anoxic zone from which the $\delta^{13} \mathrm{C}$ value of methane becomes more enriched in both vertical directions due to $\mathrm{CH}_{4}$ oxidation. 


\section{Literature Cited}

Abichou, T., D. Powelson, J. Chanton, S. Escoriaza, and J. Stern. 2006. Characterization of methane flux and oxidation at a solid waste landfill. Journal of Environmental Engineering-ASCE 132:220-28.

Alperin, M. J., W. S. Reeburgh, and J. M. Whiticar. 1988. Carbon and hydrogen isotope fractionation resulting from anaerobic methane oxidation. Global Biogeochemical Cycles 2:279-91.

Barker, J. F. and P. Fritz. 1981. Carbon isotope fractionation during microbial methane oxidation. Nature 293:289-91.

Bastviken, D., J. Ejlertsson, and L. Tranvik. 2002. Measurement of methane oxidation in lakes: a comparison of methods. Environmental Science and Technology 36:3354-61.

Beer, J. and C. Blodau. 2007. Transport and thermodynamics constrain belowground carbon turnover in a northern peatland. Geochimica et Cosmochimica Acta 71:2989-3002. doi:10.1016/j.gca.2007.03.010.

Bergamaschi, P., C. Lubina, R. Konigstedt, H. Fischer, A. C. Veltkamp, and O. Zwaagstra. 1998. Stable isotopic signatures (delta C-13, delta D) of methane from European landfill sites. Journal of Geophysical Research 103:8251-65.

Bousquet, P., P. Ciais, J. B. Miller, E. J. Dlugokencky, D. A. Hauglustaine, C. Prigent, G. R. Van der Werf, P. Peylin, E. G. Brunke, C. Carouge, R. L. Langenfelds, J. Lathiere, F. Papa, M. Ramonet, M. Schmidt, L. P. Steele, S. C. Tyler, and J. White. 2006. Contribution of anthropogenic and natural sources to atmospheric methane variability. Nature 443:439-43.

Bradley, C., A. Baker, S. Cumberland, I. Boomer, and I. P. Morrissey. 2007. Dynamics of water movement and trends in dissolved carbon in a headwater wetland in a permeable catchment. Wetlands 27:1066-80.

Darling, W. G. and D. C. Gooddy. 2006. The hydrogeochemistry of methane: evidence from English groundwaters. Chemical Geology 229:293-312.

De Visscher, A., I. De Pourcq, and J. Chanton. 2004. Isotopic fractionation effects by diffusion and methane oxidation in landfill cover soils. Journal of Geophysical Research 109:D18111. doi:10.1029/2004JD004857.

De Visscher, A. and O. Van Cleemput. 2003. Simulation model for gas diffusion and methane oxidation in landfill cover soils. Waste Management 23:581-91.

Fisher, R., D. Lowry, O. Wilkin, S. Sriskantharajah, and E. G. Nisbet. 2006. High-precision, automated stable isotope analysis of atmospheric methane and carbon dioxide using continuous-flow isotope-ratio mass spectrometry. Rapid Communications in Mass Spectrometry 20:200-08. doi: 10.1002/rcm.2300.

Frenzel, P. and E. Karofeld. 2000. $\mathrm{CH}_{4}$ emission from a hollowridge complex in a raised bog: the role of $\mathrm{CH}_{4}$ production and oxidation. Biogeochemistry 51:91-112.

Giani, L., J. Bredenkamp, and I. Eden. 2002. Temporal and spatial variability of the $\mathrm{CH}_{4}$ dynamics of landfill cover soils. Journal of Plant Nutrition and Soil Science 165:205-10.
Gooddy, D. C. and W. G. Darling. 2005. The potential for methane emissions from groundwaters of the UK. Science of the Total Environment 339:117-26.

Grossman, E. L., L. A. Cifuentes, and I. M. Cozzarelli. 2002. Anaerobic methane oxidation in a landfill-leachate plume. Environmental Science and Technology 36:2436-42.

Happell, J. D., J. P. Chanton, and W. S. Showers. 1994. The influence of methane oxidation on the stable isotopic composition of methane emitted from Florida swamp forests. Geochimica et Cosmochimica Acta 58:4377-88.

Kinnaman, F. S., D. L. Valentine, and S. C. Tyler. 2007. Carbon and hydrogen isotope fractionation associated with aerobic microbial oxidations of methane, ethane, propane and butane. Geochimica et Cosmmochimica Acta 71:271-83.

Liblik, L. K., T. R. Moore, J. L. Bubier, and S. D. Robinson. 1997. Methane emissions from wetlands in the zone of discontinuous permafrost: Fort Simpson, Northwest Territories, Canada. Global Biogeochemical Cycles 11:485-94.

Liptay, K., J. Chanton, P. Czepiel, and B. Mosher. 1998. Use of stable isotopes to determine methane oxidation in landfill cover soils. Journal of Geophysical Research 103:8243-50.

McAuliffe, C. 1971. GC determination of solutes by multiple phase equilibrium. Chemical Technology 1:46-51.

Miller, J. B., K. A. Mack, R. Dissly, J. W C. White, E. J. Dlugokencky, and P. P. Tans. 2002. Development of analytical methods and measurements of ${ }^{13} \mathrm{C} /{ }^{12} \mathrm{C}$ in atmospheric $\mathrm{CH}_{4}$ from the NOAA Climate Monitoring and Diagnostics Laboratory Global Air Sampling Network. Journal of Geophysical Research 107.doi: 10.1029/2001JD000630.

Miyajima, T., Y. Yamada, and Y. T. Hanba. 1995. Determining the stable isotope ratio of total dissolved inorganic carbon in lake water by GC/C/IRMS. Limnology and Oceanography 40:994-1000.

NWWG 1997. The Canadian Wetland Classification System. National Wetlands Working Group, Wetlands Research Centre, University of Waterloo. Waterloo, ON, Canada.

Reeburgh, W. S. 2003. Global methane biogeochemistry. 65-89. In Keeling, R. F., editor. The Atmosphere, Volume 4 of $\mathrm{H}$. D. Holland and K. K. Turekian (eds.) Treatise on Geochemistry. Elsevier: Pergamon. Oxford, UK.

Rice, A. L., A. A. Gotoh, H. O. Ajie, and S. C. Tyler. 2001. Highprecision continuous-flow measurement of $\delta^{13} \mathrm{C}$ and $\delta \mathrm{D}$ of atmospheric $\mathrm{CH}_{4}$. Analytical Chemistry 73:4104-10.

Schoell, M. 1980. The hydrogen and carbon isotopic composition of methane from natural gases of various origins. Geochimica et Cosmochimica Acta 44:649-61.

Simpkins, W. W. and T. B. Parkin. 1993. Hydrogeology and redox geochemistry of $\mathrm{CH}_{4}$ in a Late Wisconsinian till and loess sequence in Central Iowa. Water Resources Research 29:3643-57.

Strayer, R. F. and J. M. Tiedje. 1978. In situ methane production in a small, hypereutrophic, hard-water lake: loss of methane from sediments by vertical diffusion and ebullition. Limnology and Oceanography 23:1201-06.

Tarasova, O. A., C. A M. Brenninkmeijer, S. S. Assono, N. F. Elansky, T. Röckmann, and M. Brass. 2006. Atmospheric 
$\mathrm{CH}_{4}$ along the Trans-Siberian railroad (TROICA) and river Ob: source identification using stable isotope analysis. Atmospheric Environment 40:5617-28.

Teh, Y. A., W. L. Silver, and M. E. Conrad. 2005. Oxygen effects on methane production and oxidation in humid tropical forest soils. Global Change Biology 11:1283-97.

Teh, Y. A., W. L. Silver, M. E. Conrad, S. E. Borglin, and C. M. Carlson. 2006. Carbon isotope fractionation by methane-oxidizing bacteria in tropical rain forest soils. Journal of Geophysical Research 111:G02001. doi:10.1029/2005JG000053.

Tyler, S. 1991. The global methane budget. 7-38. In Rogers, J. and W. Whitman, editors. Microbial Production and Consumption of Greenhouse Gases: Methane, Nitrogen Oxides, and Halomethanes. American Society of Microbiology. Washington, DC, USA.

Van Breukelen, B. M. and J. Griffioen. 2004. Biogeochemical processes at the fringe of a landfill leachate pollution plume: potential for dissolved organic carbon, Fe(II), $\mathrm{Mn}(\mathrm{II}), \mathrm{NH}_{4}$, and $\mathrm{CH}_{4}$ oxidation. Journal of Contaminant Hydrology 73:181-205.

Waddington, J. M. and N. T. Roulet. 1997. Groundwater flow and dissolved carbon movement in a boreal peatland. Journal of Hydrology 191:122-38.

Wahlen, M. 1993. The global methane cycle. Annual Reviews Earth Planetary Sciences 21:407-26.

Whalen, S. C. 2005. Biogeochemistry of methane exchange between natural wetlands and the atmosphere. Environmental Engineering Science 22:73-94.
Whiticar, M. J. 1999. Carbon and hydrogen isotope systematics of bacterial formation and oxidation of methane. Chemical Geology 161:291-314.

Whiticar, M. J. 2000. Can stable isotopes and global budgets be used to constrain atmospheric methane budgets. 6385. In Khalil, M. A K., editor. Atmospheric Methane: Its Role in the Global Environment. Springer-Verlag. Berlin, Germany.

Whiticar, M. J. and E. Faber. 1986. Methane oxidation in sediment and water column environments - isotopic evidence. Organic Geochemistry 10:759-68.

Whiting, G. J. and J. P. Chanton. 1993. Primary production control of methane emission from wetlands. Nature 364:794-95.

Whiting, G. J. and J. P. Chanton. 2001. Greenhouse carbon balance of wetlands: methane emission versus carbon sequestration. Tellus 53B:521-28.

Xing, Y. P., P. Xie, H. Yang, Y. Ni, Y. S. Wang, and K. W. Rong. 2005. Methane and carbon dioxide fluxes from a shallow hypereutrophic subtropical lake in China. Atmospheric Environment 39:5532-40.

Zhang, C. L., E. L. Grossman, and J. W. Ammerman. 1998. Factors influencing methane distribution in Texas ground water. Ground Water 38:58-66. 